\title{
Transposition
}

Musique et Sciences Sociales

Hors-série 2 | 2020

Sound, Music and Violence

\section{Affordance to Kill: Sound Agency and Auditory Experiences of a Norwegian Terrorist and American Soldiers in Iraq and Afghanistan}

Affordance de tuer : agentivité sonore et expériences d'écoute d'un terroriste norvégien et de soldats états-uniens en Irak et en Afghanistan

\section{Victor A. Stoichita}

\section{OpenEdition}

\section{Journals}

\section{Electronic version}

URL: http://journals.openedition.org/transposition/4065

DOI: $10.4000 /$ transposition.4065

ISSN: $2110-6134$

Publisher

CRAL - Centre de recherche sur les arts et le langage

\section{Electronic reference}

Victor A. Stoichita, «Affordance to Kill: Sound Agency and Auditory Experiences of a Norwegian

Terrorist and American Soldiers in Iraq and Afghanistan », Transposition [Online], Hors-série 2 | 2020 Online since 15 March 2020, connection on 10 December 2020. URL : http://journals.openedition.org/ transposition/4065; DOI : https://doi.org/10.4000/transposition.4065

This text was automatically generated on 10 December 2020.

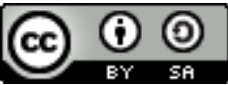

La revue Transposition est mise à disposition selon les termes de la Licence Creative Commons Attribution - Partage dans les Mêmes Conditions 4.0 International. 


\title{
Affordance to Kill: Sound Agency and Auditory Experiences of a Norwegian Terrorist and American Soldiers in Iraq and Afghanistan
}

\author{
Affordance de tuer : agentivité sonore et expériences d'écoute d'un terroriste \\ norvégien et de soldats états-uniens en Irak et en Afghanistan
}

Victor A. Stoichita

\section{Introduction: The loss of agency}

1 The assumption that specific sounds have special "powers" appears in all human societies (albeit not about the same sounds). Unusual agency is what makes "music" a distinct auditory phenomenon which stands apart from the normal workings of language and daily ecological semiosis. ${ }^{1}$ The "powers" of music depend on specific ways of listening and, in this respect, arise as a result of listener agency. That is to say that music has "effects" not because of intrinsic meanings or forces, but "because it offers specific materials to which actors may turn when they engage in the work of organizing social life. Music is a resource-it provides affordances-for world building". 2

2 The "affordance" theory is elegant because it is, at the same time, parsimonious and powerful. With little hypotheses about music (nothing "intrinsic" in it anymore), it explains most of what people do with it. By putting the accent on listener agency, sound becomes a medium for distributed cognitive moves. Music is "a persistent environmental resource supporting the development of various experiences and embodied practices", something like an "emotional scaffolding", writes Krueger. ${ }^{3}$ The affordance theory of music is also interesting, in another respect, because it does not start by reproducing the "basic ontological fallacy: that music is essentially a thing 
which refers to another thing". ${ }^{4}$ By viewing music as a resource for action, it avoids many pitfalls of classic semiotic approaches.

Where it falls short, however, is in also explaining why people persist in putting more agency in sound than what it really should have. When they talk about their musical experiences, even the most rationalist listeners report feeling an external force, a "drive", which affects them in various ways from the outside. ${ }^{5}$ An affordance, in Gibson's original terms, should be something more inert than that. The affordances of an environment "are what it offers the animal, what it provides or furnishes, either for good or ill". ${ }^{6}$ An affordance is neither "objective" nor "subjective". It cuts across that dichotomy and "points both ways, to the environment and to the observer". ${ }^{7}$ Yet an affordance does not require consciousness, not even some kind of understanding. It is a low-level feature of daily perception, shared by all sentient beings. It starts as "an invariant combination of variables, and one might guess that it is easier to perceive such an invariant unit". ${ }^{8}$ Our world is full of affording objects, but we do not attribute agency to all of them.

4 To account for this, DeNora refers in short to actors' tendency to "erase the work they do of configuring objects and their social implications (...) Indeed, it would seem part of the natural attitude (...) to 'forget', paraphrasing Marx, that we are oppressed by the things we have helped to produce. This 'forgetting' is the cognitive practice of reification". ${ }^{9}$ By this account, the "reified" musical agent is a kind of collective and systematic mistake. It results from a cognitive bias, thus it cannot be amended through mere knowledge (contrary to the proletarian's mistake). I find it difficult to adhere to this scenario, at least without a precise explanation of how-for so many people in so many cultures-the illusion arises that music "has" powers and agency of its own.

The present paper does not provide a general solution for this. Instead, it contrasts two ways in which listeners took advantage of musical affordances-or were they agencies? -as a source for "motivation". The action for which they wanted motivation was armed violence. This might seem a strange topic; it is, indeed, a rather peculiar way to use music in social life. But precisely because of this, it encourages listeners and researchers alike to clearly explain how music comes in handy in the accomplishment of the purported action.

6 There are at least two very different ways to listen to music as a motivator for armed violence. One is reflected in the practices of American soldiers in Iraq and Afghanistan. ${ }^{10}$ A number of them had "battle playlists" to motivate them before going on a mission. The other is reflected in the "manifesto" produced by Norwegian terrorist A. B. Breivik during the preparation of his attacks in 2011. In this complex document, Breivik repeatedly stated that specific music helped him to sustain his motivation.

7 Breivik belongs to the same generation as the American soldiers and grew up in roughly the same type of media environment. Like them, he reported using his iPod intensively as a tool to help him "tune in" to different kinds of cognitive activities. He was explicit about the influence that popular movies and video games had on his worldview. A similar influence has often been discerned in the "battle playlists" of American soldiers, ${ }^{11}$ even though the terrorist's and the soldiers' motivational music sounded very different.

8 In a previous work, I suggested that this difference was coherent with a significant divergence in their framing of danger and violence. ${ }^{12}$ The terrorist acted alone, of his own will, and placed great emphasis on notions of "martyrdom". The soldiers were paid 
as professional fighters, in a situation "where individuals were required to overcome their own opinions and emotions in order to go forth and do what was demanded of them". ${ }^{13}$ Here, I propose to analyse more precisely how music actually "worked" in practice, for these two kinds of listeners. What did it "afford" to them?

9 I will review various proposed explanations of Breivik's and the soldiers' motivational tastes. Then, expanding on a hint from Wilson, ${ }^{14}$ I will argue that for the US troops and for the "lone wolf" terrorist, motivation was primarily an exercise in imagination. Music helped them to project an ideal kind of confrontation which, in effect, hardly ever took place. This links the current paper to broader discussions of "global war" 15 and of the increased porosity between military and civilian ideals of violence. We will also see that while Breivik's music provided him with a mere scaffolding for his daydreams, soldiers' "battle playlists" instantiated an agentive force which they could confront.

\section{A terrorist's motivational music}

10 Anders Behring Breivik ${ }^{16}$ has been described as a "lone wolf" killer, a person "carrying out mass violence in an individual capacity". ${ }^{17}$ On the $22^{\text {nd }}$ of July 2011 , he blasted a bombed van in the centre of Oslo, killing eight people. He then proceeded to the island of Utøya where he shot 69 others, mostly teenagers. Right before embarking on what he called his "mission", Breivik sent a document of over 1500 pages to around 100 email addresses, in which he mentioned music as an important ally in sustaining his motivation and performing what he called "self-indoctrination":

I simulate/meditate while I go for a walk, playing my Ipod in my neighbourhood. This consists of a daily 40 minute walk while at the same time philosophising ideologically/performing self-indoctrination and the mental simulation of the operation while listening to motivational and inspiring music. I simulate various future scenarios relating to resistance efforts, confrontations with police, future interrogation scenarios, future court appearances, future media interviews, etc. or I philosophise about certain articles in the book. This daily mental exercise or ritual keeps me fully motivated and charges my batteries. ${ }^{18}$

Breivik's compendium enabled many conjectures about what might have been the terrorist's mental evolution. It was actually by analysing this document, with special focus on its writing style, that the second team of forensic psychiatrists who assessed Breivik found him to be responsible for his actions, overturning the conclusion of a previous assessment. ${ }^{19}$ The second team concluded that Breivik had clear delusions of grandeur, but also demonstrated an "understanding of the potential emotions his reader would be feeling". ${ }^{20}$ Moreover, the team found that he did not have "false, fixed beliefs that could not be modified". ${ }^{21}$

12 A major difficulty in assessing Breivik's mental soundness was that his world was replete with imagination and virtuality, along with self-posing and deception tricks. He presented himself as a "justiciary knight of the templar order" and for that purpose created a uniform "which looked like a fusion of the Crusades and a character out of the PC game Assassin's Creed". ${ }^{22}$ At his trial, he declared having spent an average of 7 hours a day over the previous years playing World of Warcraft. In the aftermath of his arrest, he made a number of counterfactual declarations about non-existing threats, including the pretence that he had swallowed a detonator meant to blow up several other locations. ${ }^{23}$ In general, Breivik was very consciously committed to "the creation 
of a fantasy world created and controlled by [his own] vision". ${ }^{24}$ For this effect, which he called "self-indoctrination", he used specific music.

The tunes which he mentions as allies in sustaining his motivation were of three kinds:

Music by Swedish singer Saga. Breivik understood the lyrics, transcribed some of them in his compendium and recommends learning them by heart.

Music composed by Knut Avenstroup Haugen, featuring Norwegian singer Helen Bøksle. Breivik states that the lyrics are in old Norse, but gives no further indication of their relevance to him (it is uncertain whether he understood them at all). He relates the music to the video game Age of Conan..$^{25}$

16 An instrumental piece by Clint Mansell. The original composition was entitled "Lux Aeterna", which is also how Breivik refers to it. However, he recommends listening to its adaptation for the movie Lord of the Rings II. ${ }^{26}$ This piece was of special importance to Breivik. He described it as the suitable soundtrack to play on repeat on his iPod during his "mission" (it is uncertain whether he actually listened to it or not). He also recommends it as a starting point for the anthem of the conservative European federation he wished for.

This media file cannot be displayed. Please refer to the online document http:// journals.openedition.org/transposition/4065

Stroud suggested that music helped Breivik to feel part of a larger community despite the fact that he had to conceal his preparation and act in complete isolation. ${ }^{27}$ This analysis is supported by his insistence on the inspirational potential of Saga's music (1). According to Stroud, she was already a "high-profile figure in the extreme-right music scene which promotes the ideology of white nationalism and supremacism". ${ }^{28}$ Teitelbaum argued however that Saga's lyrics were actually not coherent with Breivik's ideology, being closer to neo-Nazi and skinhead movements (which Breivik despised). ${ }^{29}$ Breivik could have found interest in Saga's music because it "may have presented him a safe domain in which to experiment with ideologies he otherwise condemned". ${ }^{30}$

Apart from their content, the linguistic pragmatics of Saga's lyrics-at least those cited by Breivik-are very listener-inclusive. Their use of personal pronouns is usually limited..$^{31}$ Many verses simply chain impersonal statements, loosely coupled with an occasional first person in the singular ("I") or plural ("we"), and occasionally shifting between the two. In effect (ideological content excepted), the singer could be anyone, and the song could be an impersonal hymn.

Life is a struggle in these changing times

Thoughts once natural now classed as hate crimes

Those now in power they fear no one but one

a man with open eyes and a sober mind so strong

It's been said before - but still we do not heed...no!

To free the enslaved minds of the sleeping mass

We must cast away the yokes ignore status and class

[Beginning of "One Nation Arise", the first lyrics quoted by Breivik under the

heading "The best vocal English tracks [from Saga]".]

The views expressed come with few references to Saga's autobiographical self. Nothing in her songs resembles the highly agentive and personalized "I" of rap lyrics to be discussed hereafter. In general, the listener can readily identify him or herself with the position of the song's utterer. 
21 If Saga's music may have helped Breivik imagine emotional connections with a larger right-wing community, it is more difficult to extend this argument to his other motivational tracks. Nothing indicates that they were important to other people sharing his political views, or that he had any grounds to think that they were. What is immediately striking in these pieces of music (2. and 3. above), is that they are "tragic" in mood, but of a relatively "ambient" musical making. They contrast in this respect with the more "aggressive" styles that motivated American soldiers (typically rap and heavy metal, as we shall see). In (2) and (3), no guitars, no distortion, no screaming voices. In (2), the main "feature" is a solo female voice. It is surrounded in reverb, giving the feeling that she sings from some distance. There are few lyrics, few consonants, mostly stretched vowels. The strings (probably synthesized) play long drone-like notes in the lower range. The harmonies are mostly stable, with few, slowly changing chords. Drums can be heard only on two of the three tracks mentioned by Breivik. They sound like large, low-pitched, double-headed drums (no snares, no cymbals). A heavy reverb effect is applied to them as well. This general description applies to the three tunes mentioned by Breivik, but not to the overall soundtrack of the video game. ${ }^{32}$ Breivik seems to have focused on those parts which were both "heroic" and relatively devoid of salient musical features. One could describe them as tunes but also as soundscapes.

"Lux Aeterna" (3) would seem to elicit a rather different description. Breivik wrote that it was "very inspiring and invokes a type of passionate rage within you". ${ }^{33}$ According to musicologists Bjorøy and Hawkins:

Something foreboding lies in the deep-layered density of textures in the music; the score is rife with passionate rage and menace (...) With full sonic force, the listener or shooter is bombarded by a flood of powerful gestures, all of which build up into a feeling of anxiety that verges on the frenetic. Combat and war are sensationalized by the musical clichés of the scoring-lush, sweeping strings, glossy production, and intense musical processes that include pompous and gradual crescendos, fastpaced rhythms, and rich harmonic devices. ${ }^{34}$

Yet "Lux Aeterna" is also, in a sense, rather minimalistic. It is built around one nostalgic motive which in turn revolves around one tonal centre (3 degrees up, 3 degrees down). It remains in the same minor key throughout. Layers of instruments are simply added to the initial motive with occasional short variants. A choir sings one open syllable (no lyrics). Drums mostly punctuate the beat. The rhythm might seem "fast-paced" compared to (2), but it is still slower than the common tempos in the soldiers' rap and heavy metal. Overall, "Lux Aeterna" uses many cinematic effects, as Bjorøy and Hawkins point out, but it also maintains throughout a sort of "availability" typical of film soundtracks. Without the filmed images, the listener is left with considerable room to supply his own.

Both (2) and (3) fall within the range of "honorable duty" soundtracks to violence. The term was coined by Pieslak to capture the spirit of the main approach to creating soundtracks for war and adventure scenes prior to the $1980 \mathrm{~s}^{35}$ During the $1980 \mathrm{~s}$, drumbeats, distorted guitars and high-energy voices started to take over, in line with a general come-back of heavy-metal in Euro-American musical tastes. ${ }^{36}$ According to Pieslak, these new sonorities shifted the focus of war scenes from heroism to action and adventure. However, "honorable duty" soundtracks remained favourites for battles located in historical or mythical pasts, like those in Lord of the Rings, or Age of Conan. In addition to these fantastic legendary worlds, their values of heroism, bravery and 
destiny probably appealed to Breivik. Right after providing a link to "The Dreaming Anew", he wrote:

Imagine the following; at the end of your mission, when you have completed your primary objectives - imagine fighting for your life against a pursuing pack of system protectors ([...] also referred to as the police). You try to avoid confrontation but they eventually manage to surround you. You hear this song as you push forward to annihilate one of their flanks, head shooting two of your foes in bloody fervor trying to survive. This angelic voice sings to you from the heavens, strengthening your resolve in a hopeless battle. Your last desperate thrust kills another two of your enemies. But it isn't enough as you are now completely surrounded; your time is now. This voice is all you hear as your light turns to darkness and you enter into the Kingdom of Heaven. This must surely be the most glorious way to claim the honour of martyrdom in battle. ${ }^{37}$

Like many users of personal stereo devices, Breivik "soundtracked" his thoughts with music during his daily walks. The "cinematic" aspect of his experience is common. ${ }^{38}$ What is interesting is that the scene above goes on post-mortem, suggesting that Breivik occupied not so much his own part, as perpetrator of the mass killing, but the part of the director, watching the whole movie from posterity. ${ }^{39}$ This was possible because "The Dreaming Anew", like all of Breivik's motivational music, affords a move to a third-eye position. Tracks (2) and (3), in particular-being virtually devoid of lyrics and maintaining minimum melodic content, rhythmic complexity and chord progressions-end up merely creating "ambiance". Their dominant minor key is culturally compatible with a variety of thoughts ranging from nostalgia to heroic tragedy. Their wide reverbs are ecological markers of large spaces. ${ }^{40}$ They leave a lot of "room" for the listener's mental projections ("room" which might initially have been left for the visual actions of the film or play).

Breivik used "The Dreaming Anew" along with a slide-show of still text and images to make what he called the "marketing movie trailer" of his compendium. ${ }^{41}$ When that video was projected during his trial, he was visibly moved to tears. ${ }^{42}$ One might guess that listening to that music while watching his image and thoughts on screen might have re-enacted his narcissist fantasies of being a martyr. For the rest of the hearings in court, his facial attitude remained remarkably emotionless. ${ }^{43}$ Breivik was tragically successful at killing unarmed civilians, but never fired a single shot at an armed "system protector". ${ }^{44}$ During his trial, he nonetheless referred repeatedly to himself as a martyr. In 2014, he sued the penitentiary administration on the grounds that he was being "tortured" in prison. Amongst other grievances, he explained that he was only allowed to own an obsolete Play Station 2 and was denied the right to choose the games himself. 45

Breivik seems to have used (2), (3), and possibly (1) as well, as extensions of his mental horizon. They provided him with additional space, to step outside his mind and take a third-eye view of himself. In those musical daydreams, he managed to view himself as a martyr, and that certainty seems to have stayed with him ever since. Of course we cannot know where his "simulations" and "self-indoctrinations" would have taken him had their soundtrack been different. One might suspect, however, that heavy metal and rap, which many American soldiers found motivational, would not have worked for him. Breivik wrote that he "hated" heavy-metal for its violence and found rap (produced after the 1980s) too "brutal" ${ }^{46}$ It is not uncommon for perceived violence and brutality to turn some people away from these musical genres, but in the mindset of a person preparing to perpetrate mass murder, these grounds for distaste might 
seem paradoxical. It is clear throughout Breivik's compendium that he had no problem with violence in general, and that he accepted brutality as an unfortunate but, in his view, necessary aspect of his project. His distaste for rap and metal might have arisen not so much from their symbolic references to violence, but from the ways in which they instantiated and brought to the present, in the here and now of listening, a kind of agentive force which opposed his own imagination. As we shall now see, confrontation seems to be precisely what some American soldiers sought in listening to rap and metal prior to their missions.

\section{Soldiers' motivational music}

Various sources indicate that a number of American soldiers in Iraq and Afghanistan consciously used music as a motivator to "pump themselves up" before their missions:

A number of studies on the subject of soldiers' listening practices all mention the existence of "battle playlists". ${ }^{47}$ These studies were all based on first-hand interviews with the soldiers. None had direct access to the deployed troops. Some of them also included additional input from the soldiers' "military blogs" and from the other types of sources listed hereafter.

One documentary filmed in Iraq in 2003-04 was entirely devoted to music at war. It dealt extensively with the motivational uses of music (Soundtrack to War, by George Gittoes). Motivational music also appears incidentally in other documentaries filmed amongst the troops in Iraq (like Gunner's Palace by M. Tucker, and Occupation Dreamland by Ian Olds and G. Scott).

Audiovisual pieces with scenes of combat and motivational soundtracks were produced by the soldiers themselves and distributed over the internet. These "war videos" were discussed by Pieslak, ${ }^{48}$ and their aesthetics was analysed in detail by Sumera. ${ }^{49}$ Many of them are still available on the internet. It is noteworthy that some of these videos were also shown to new recruits during basic training, and that the US Navy produced images in the same musical spirit for its recruitment commercials. ${ }^{50}$

These sources jointly indicate that the use of music as a motivational resource by US soldiers in Iraq and Afghanistan was not an isolated individual phenomenon but indeed a technique shared by many. The accounts converge on the particular significance of two musical genres for motivating soldiers before action: gangsta rap and heavy metal.

These styles of music had already been a topic of controversy in civilian life for their "negative" and "violent" features. Their prominence in the "battle playlists" of American soldiers led some media to portray the latter as "brutes listening to brute music to be even more brutish". ${ }^{11}$ Interestingly, not all soldiers resisted this qualification. The most shared and commented "war videos" posted on the internet were made of chosen combat images carefully synced to nü metal tracks. Then, some soldiers-especially amongst those endowed with more bureaucratic tasks-would stage images of themselves according to this aesthetic of power. "Even soldiers like to play soldiers", concludes Sumera. ${ }^{52}$ One former soldier to which this aesthetics did not appeal puts it similarly to Gilman: "[For] some of them, it was like playing GI Joe everyday". ${ }^{3}$

4 The salience of "battle music" has tended to overshadow the many other ways in which American soldiers listened to many other types of music. Generally, the iPod was a 
conspicuous feature of soldiers' equipment. ${ }^{54}$ They used it to listen to a wide array of music "depending on their emotional and social needs at any given moment". ${ }^{55}$ Soldiers were generally quite explicit about the fact that "music was a technology of the self that enabled [them] to fine-tune their mental and emotional states". ${ }^{56}$ Collectively, they had music that helped them to relax, to sleep, to think of home, to alleviate feelings of sadness, to party and bond together, to think of their beloved, to escape a hypermasculine environment, to live through their frustrations with the hierarchy... and to motivate them before their mission. How exactly did rap and metal come to seem particularly fitted for this latter purpose? Several answers have been proposed.

\section{Does "aggressive" music motivate?}

Maybe gangsta rap and heavy metal are intrinsically "aggressive". Gangsta rap is known for its "explicit" lyrics delivered in "angry", "punchy", "up in your face" vocal styles. Heavy metal is known for its loud, noisy distortion, its screaming voices, its high speed drumbeats. Visual icons of warfare are frequent in its iconography. Generally, "heavy metal is war" is a kind of cliché about the genre. In their testimonies, several soldiers reversed this into "war is heavy metal". According to J. Pieslak:

The violent expression of power associated with firing a gun becomes sonically replicated in the rhythms of the music. Because these rhythms are articulated in ways that resemble gunfire, soldiers may feel empowered by the music that, for them, evokes the sounds of combat. ${ }^{57}$

Timbre could also work as a motivator:

The heavy guitar distortion characteristic of metal songs "pumps up" soldiers by timbrally conveying feelings of intensity and aggression. The distortion psychologically empowers soldiers by communicating an energized aggressor's mindset. ${ }^{58}$

In support of the timbre hypothesis Pieslak quotes Whiteley:

Naturally produced sound waves have only a few harmonics, but these (distorted) "clipped" waves have many, especially at a high level, and this is what gives off the piercingly painful effect. ${ }^{59}$

Now let us suppose that Whiteley's analysis is correct and that distortion does have the psychological properties described. How does one feel "empowered" by listening to something that has a "piercingly painful effect"? Why would a sonic replica of a firing machine gun motivate the listener for combat? One can readily understand how "aggressive" music would result in the listener feeling "aggressed" (this is indeed tautological), but certainly not all aggressions communicate to the victim "an energized aggressor's mindset". Another argument must be supplied to explain how "aggressive" music becomes, for some people, motivator of violent actions.

If the "affordance" view is right, music should be, generally speaking, "a medium for removal from and refurnishing of social environments so as to make existence habitable, hospitable, better". ${ }^{60}$ The quote might seem misplaced in the context of "battle music", but even in DeNora's book, it appears just a few pages after a depiction of American soldiers in Iraq motivating themselves with music in their armoured tank. ${ }^{61}$ Listening to "war" before going to war is really a good test for affordance theories because it raises the question: how did it help? How did it make things any better? 


\section{Are metal and rap modern equivalents of historical battle music?}

40 A comparison with motivational music used in previous wars only highlights the question. Historical battle music typically valued notions of heroism, God and the homeland. This is not what rap and metal are about. If anything, they would rather oppose their "negativity" 62 to the classic values that motivated the patriot warrior. Historical battle music often adapted popular dance tunes which the soldiers would link to a sense of collective wellbeing. ${ }^{63}$ It provided comfort and reassurance in contrast with the battle to come. They were precisely not "war".

American soldiers also had music to remind them of their homeland and patriotism, generally falling within the range of "country music", ${ }^{64}$ but "country music" never appeared on their "battle playlists". Soldiers did not seem to find it adequate when they were preparing for combat. In fact, some of them consciously chose motivational tunes that would not remind them too much of "home". ${ }^{65}$ This is a significant difference with previous battle music.

\section{Is motivation like trancing?}

Some soldiers stated that music would take them out of their normal selves and motivate actions beyond their own personal will.

["Go to Sleep" by Eminem] is a very negative song, and I'm almost even embarrassed to say it was our theme song. But hey, that's what happens in war. You've got to become inhuman to do inhuman things. And by that I just mean, shooting a weapon in the direction of a living person.... The worst part is that I didn't used to use profanity, but at some point I snapped. Now that I've returned to normal, I can't listen to this song. ${ }^{66}$

Taken literally, Grisham's assertion would mean that music could lead one beyond one's "humanity", nearly against one's will. Trance, and its quieter corollary of "deep listening", ${ }^{67}$ are experiences where the subject feels that musically induced emotions "take control" of his or her actions. Pieslak then proposed a parallel:

Metal and rap can create a deep listening experience for some soldiers in which they adopt attitudes about violence and dehumanization not typically associated with their autobiographical self. Music in this circumstance induces an aggressive mindset and operates as a pretext for the possibility of violent action. ${ }^{68}$

Echoes of this idea did not always reflect Pieslak's cautious tone as well. ${ }^{69}$ But caution is key here, as there is a crucial difference between soldiers and trancers: soldiers do not use music as an accompaniment for action. The logics of trancing and deep listening are that music works as an immersive media which enables the listener to live another reality while it lasts..$^{70}$ On the other hand, whatever "deep listening" soldiers engaged in, it was a pretext for violence, as Pieslak precisely states.

Music typically accompanied actions like putting on bulletproof vests, checking backpacks and ammunition, and possibly driving and waiting for long periods in armoured vehicles. Many soldiers actually turned the music off when they went "outside the wire". ${ }^{71}$ But by all accounts, even if music was going on and the soldiers were attacked by surprise, they stopped hearing it to concentrate on the fight:

As soon as guns start firing and you're fighting your way out of an ambush, or those tanks starts going off, or those RPGs start going off, you don't fuckin' hear that 
music. It's all just instinct, man. It's all what you got inside of you that starts

coming out. ${ }^{72}$ popular American media. ${ }^{73}$ This observation has been presented to explain music's later motivational uses by the soldiers.

For a generation that grew up with filmic depictions of battle and first-personshooter video games, both of which tend toward music-heavy soundtracks, it is no surprise that the experience of live combat was at times interpreted through the prism of war movies or games. ${ }^{74}$

As we have seen, people of the same generation were exposed to at least one other standard way of soundtracking violent actions. In theory, American soldiers could have turned to "honorable duty" music, as Breivik did. Another difficulty is that, also like Breivik, they could have included actual soundtracks in their playlists. Instead, the tracks the soldiers deemed motivational were full-fledged, stand-alone musical pieces. They merely belonged to the same musical genres as movie soundtracks. I suggested above why this could make a difference for the listener: soundtracks are often composed to be flexible and leave "room" when needed for the visual action and the occasional replicas of the script. There is no such requirement for stand-alone tracks, which can freely catch and occupy the listener's attention with their auditory features.

But the most important aspect is that, in fact, contrary to what Daughtry seems to suggest, the battle playlists were never used as a soundtrack to an actual "experience of live combat". Heavy metal was used as a soundtrack to images of conflict, on "war videos" for instance. Before a mission, rap and metal would accompany, at most, the experience of thinking in general terms about it. But in their testimonies, soldiers do not actually depict motivational music as a realm in which to imagine with some precision what they are about to do (nothing like the mental simulations familiar to Breivik). Rather, music offered the benefit of suspending unneeded interactions and helping one focus on one's task:

For some reason, when we had the music on in the truck, there was less talking and more you were paying attention to your sector. You were on your guard a little bit more, because you were able to sustain your horizon, and you didn't have to keep up with the conversation. You just focus on the music, and focus on your sector, and make sure that you weren't getting shot at. ${ }^{75}$

50 As a soundtrack, music afforded a continuous sense of interaction, but not with one's colleagues, and not with a visible enemy either. It helped focus on an otherwise "empty" sector. When an enemy eventually surged, as we have seen, the music stopped.

\section{Is motivational music a substitute for violence?}

51 Music was then, in significant ways, not a "soundtrack to war". It was certainly a way through which the soldiers could "frame" their engagement in specific actions (like watching an empty sector, waiting in a van, or putting on a bulletproof vest). In DeNora's terms, "[M]usical framing occurs when music's properties are somehow 
projected or mapped onto something else, when music's properties are applied to and come to organize something outside themselves".$^{76}$ The cognitive product of musical framing belongs to the wider category of metaphors. In Lakoff and Johnson's classic definition, "[T]he essence of metaphor is understanding and experiencing one kind of thing in terms of another". ${ }^{77}$ One of their first examples is, precisely, the metaphor ARGUMENT IS WAR. ${ }^{78}$

"His claims are indefensible", "his criticisms were right on target", "I've never won an argument with him"... All such utterances are, according to Lakoff and Johnson, instances of this metaphor. It structures the concept of ARGUMENT by mapping onto it the properties of WAR. The mapping is constitutive of the target concept since, in the end, an argument is little more than a discussion understood as a kind of war. ${ }^{79}$ One interesting point for our purpose is that the cognitive usefulness of the metaphor depends on the concept of WAR being more structured and clear, to start with, than the concept of ARGUMENT. Only then can WAR serve to understand ARGUMENT. This structure does not depend on experience (people typically encounter more arguments than wars in their lives). What people map onto arguments is not their experience of war, but their knowledge of the concept of WAR.

As a metaphor, HEAVY METAL IS WAR parallels ARGUMENT IS WAR. It uses the concept of WAR to understand the experience of HEAVY METAL. Then when American soldiers reverse it into "war is heavy metal", they in effect bring closer to their prototypes a confuse experience of violence which is not quite WAR. Two armies clashing together would probably have been prototypical of WAR. But what about a state army of professional soldiers opposing "terrorists", "insurgents" or civilian resistance ${ }^{80}$ In that situation, rap and metal could have motivated the troops not as soundtracks to WAR, but as substitutes for it.

This hypothesis was proposed by S. Wilson:

Heavy metal, as the musical illusion of massacre, is also the cultural compensatory repetition of the trauma that for many American combatants may have been essentially missed. In war, metal seals off Americans from the real world of their own un-making in another world of pleasurable sonic madness and pumpin' aural carnage-a world of their own. ${ }^{81}$

Maybe motivational music worked for the soldiers as it did for Breivik: not as a means to connect them to forthcoming dangers or violence, but quite the opposite: as a tool to disconnect them from the most uncomfortable aspects of their mission. Wilson's intuition might also explain why the soldiers were motivated by "aggressive" music, while a mass killer like Breivik was not.

\section{"It seems they don't want our help"}

The conflicts in Iraq and Afghanistan opposed highly asymmetrical powers. American soldiers could be targeted, wounded or killed, but the risks were largely higher on their opponents' side. American airplanes were virtually invulnerable and could drop highly efficient guided bombs nearly anywhere. Consequently, airborne soldiers described most of their missions as "routine". ${ }^{82}$ Soldiers on the ground came in closer contact with the local populations, and often expressed ethical concerns about the rationale of an operation where they seemed to be invading another country.

We're dumping so much money into this country... For what? Just to have these people shoot at us, kill us, blow us up by whatever means they can... I don't 
understand it. We're trying to help these people and it seems they don't want our help..$^{83}$

I can't really blame these people for not wanting us to be here. You know, I wouldn't want some other country to come in and just take over our country and... drive through our streets and... I guess we're pretty intimidating when we roll in, you know, get fucking weapons pointed out every which way, and... I'm sure it scares the shit out of these people and I guess I'd figure they have to fight back. ${ }^{84}$ listener's agency. Let us consider for instance "Go to Sleep", which appears in Grisham's quote above as a kind of "anthem" for his unit. The voices are recorded close to the microphone with dentals and plosives $(t, d, p, b)$ left to saturate, as if the rappers were speaking or shouting directly in the listener's ears. Voices are also thoroughly compressed, levelling out their dynamics and bringing up their softer parts. Reverbs are kept to a minimum, preserving a sense of closeness. Eminem's voice is doubled throughout, in two takes. He says that he comes alone ("Me do this one all by my only, I don't need fifteen of my homies..."), but his voice speaks double. Ambient sounds are added on the chorus to give it more "punch". Gunshots and other weapon-related samples coincide precisely with specific syllables, building a complex polyrhythm: ${ }^{86}$

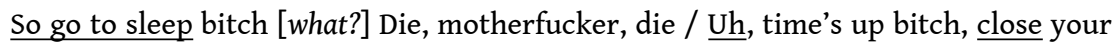
eyes

* Go to sleep, bitch [what?] / Why are you still alive? / How many times I gotta say, close your eyes?

* Go to sleep bitch [what?] / Die, motherfucker, die. Bye, bye, motherfucker, bye, bye

* Go to sleep, bitch [what?] / Why are you still alive? / Why? Die motherfucker, ha ha ha

Key: gunshot / explosion / loading a gun / *. gunshot between words

This media file cannot be displayed. Please refer to the online document http:// journals.openedition.org/transposition/4065

"Voice as a weapon" is a recurring theme in rap. The lyrics here stage a confrontation between "I" (first person) and "you" (second person). "I" is clearly identified and personalized. It refers to the biographic self of the rapper. "You" could be anybody beyond the microphone, the headphones or the loudspeaker. If it were normal speech, it would be "you", the listener. But songs are special linguistic artefacts. They also afford the listener's identification with the first person (the "I" in the lyrics). This is how soldiers can sing along with Eminem, like Grisham (quoted above) and his squad before going on a mission.

Transposition, Hors-série 2 | 2020 
61 Correct delivery of rap lyrics requires specific skills. The "I" in rap lyrics is also a virtuoso speaker, a master of language ${ }^{87}$ The first-time listener is typically left trying to keep up, grasping to make out the meaning of the words, always a bit behind. The words come quickly and numerously, are hardly ever repeated, and the meter and rhyme patterns are always changing. Breivik could advise his potential followers to learn Saga's lyrics by heart; the same advice for Eminem would significantly raise the level of difficulty. By default, the listener is in the position of the assaulted, dominated patient of the rapper's flow-only gradually able to move closer to the first-person position, and then only for certain parts of the song (typically the chorus).

Heavy metal is also replete with tropes of power and madness. ${ }^{88}$ Pieslak's analysis is probably right: metal affords direct contact with (and possibly insight into) "an energized aggressor's mindset". But here again, the listener is by default in the position of the dominated patient of the aggressive force. In a discussion with B. Joseph about the use of music in torture, S. Cusick argues that any music-and in fact any environmental feature-might be "pushable across an invisible line [beyond which] ordinary experience becomes extraordinary, horrible, and capable of breaking your very subjectivity". ${ }^{99}$ Many types of music were used by American soldiers to "break" their captives. However, in reports on musical torture, heavy metal appears more frequently than any other genre. This could be because it was indeed used more, or it could be that it was overrepresented in the subsequent descriptions. In any event, heavy metal stood out with respect to other genres, perhaps because its ideal of "madness" came with an aesthetic tendency to push things across the "invisible line" anyway. This tendency could have increased its perceived effectiveness, while also mitigating the soldiers' moral discomfort. With metal, there seemed to be at least some porosity between music's recreative and punitive uses..$^{90}$

In their introduction to a book called Virtual War and Magical Death, Whitehead and Finnström argued that war is now always global, in the sense that "there is a seamless continuity between virtual and material war, or more properly between war online and offline". ${ }^{91}$ In their analysis, "[T]he actual killings on the battlefields, wherever they happen to be located, are intimately linked to an emerging virtual space created by news and cinematic and gaming media as well as the mediating and mapping technologies of contemporary military violence". ${ }^{92}$ In the management of this virtual space, one might find that music is, generally speaking, a useful asset. Compared to other immersion technologies, it is remarkably low-cost and portable. It has probably always been so, and mobile listening devices merely enhance the listener's options to flexibly "furnish" his or her environment through music. ${ }^{93}$ In theory, such devices have also levelled accessibility, since anyone with access to the internet can now pick from the same global pool of downloadable music. In relation to the pervasive space of "global" war, different musical choices still nevertheless point to different imaginaries of armed violence.

As a mental experiment, let us imagine a swap: Breivik listens to rap and heavy metal, and the soldiers listen to "Lux Aeterna". How would this work? Nothing would prevent the terrorist from still plotting the massacre. But his attempts to look upon himself as a martyr would probably be at odds with the strong tropes of personified agency in the music. The virtuoso "gangster" poet, or the "mad" metal guitarist, do not quite "afford" that kind of emotional indulgence. On the other hand, if American soldiers 
were to seek motivation in "honorable duty" soundtracks like "Lux Aeterna", it would probably bring their focus onto aching considerations about the rationale of their action. C. Coker argued that the development of war technologies that mediate violence and provide asymmetric safety to the soldier resulted in a corollary decrease of the ethics of "sacrifice". War then became ethically questionable, because "without sacrifice or the willingness to risk death oneself, war cannot be 'sacred', and if it cannot be that it cannot be ethical" ${ }^{94}$ Soundtracks like "Lux Aeterna" or "The Dreaming Anew" were suitable workspaces for simulations that would take advantage of their tragic or nostalgic moods. Accordingly, their potential to motivate disenchanted soldiers who did not quite believe in the rationale of their war would be low.

\section{Conclusion}

The comparison proposed in this paper has limits which should be highlighted. Firstly, it relies on testimonies rather than on direct observations. Breivik's compendium is a first-hand "ego document", but clearly not all of it was written with factual accuracy in mind. Soldier testimonies were mediated by research and documentary projects which did not necessarily seek to address the workings of motivation through music. On the soldier's side, the comparison is moreover at risk of unduly homogenizing listening practices that were probably diverse. Not all soldiers had "battle playlists", and those who did used them in various ways (collectively, individually, before leaving the base camp, in the tank, etc.).

Despite these limits, I hope to have shown that the comparison reveals at least a contrast: the terrorist's motivational music contrasts with that of the soldiers. This can hardly be attributed to generational or cultural divergences, especially as video games and films of roughly the same fabric play a significant role in both cases. My point was that the observed divergence was not just a matter of random "taste", either. There is a kind of logic in the fact that American soldiers "pumped themselves up" with aggressive music while Breivik found inspiration in soundscapes of epic nostalgia.

One might say that different affordances in the music constituted different pathways to motivation. The terrorist's playlist indeed afforded imaginary pathways and mental navigation. Its relative emptiness enabled the listener to project his agency in a world of fantasy. A "predator kind of music", on the other hand, left little room for that.

Breivik was all about controlling his body, his thoughts and his mission. The soldiers, however, wanted their "battle playlists" to transform them from the outside. Music was to them an external source of energy. This was not because it was intrinsically "energetic": at least, an American listener would probably use this label for many other types of music that American soldiers would have ruled out of their "battle playlists". ${ }^{95}$ If the analysis presented here is correct, the primary usefulness of "battle music" to these soldiers was its oppositional character. Gangsta rap and heavy metal instantiated highly agentive forces which engaged the listeners in direct confrontation. It was this sense of confrontation which some soldiers found energizing. Their "battle music" gave them, like no other music before, a close taste of what a prototypical battle should feel like. It contrasted with the situations that soldiers on the ground typically encountered during their missions: sporadic violence and diffuse opposition from underequipped and poorly trained "hostiles" who might even turn out to be civilians. 
69 If heavy metal and gangsta rap made possible a kind of violent encounter, the next question is: with whom? Battle playlists were eclectic and sampled from a wide range of artists. There is little evidence that the artists' biographies mattered in any way to the soldiers. ${ }^{96}$ One might also observe (with Walser, Pieslak and others), that heavy metal is particularly not about giving transparent access to the "humanity" of its makers. It strives more often to convey a sense of monstrous "insanity", to which effect it employs various kinds of distortion: electronic distortion on the guitars, vocal distortion of the lyrics, drums that oscillate between rhythm patterns and "power blasts". On stage and in video clips, it is not uncommon for musicians to hide or to distort their human faces by using heavy make-up or masks. While agency, in general, pervades the sounds of heavy metal, it is also set apart in various ways from the agency of "normal" human beings.

70 Then does it mean something, after all, to talk about sounds having an agency of their own? I have argued elsewhere with B. Brabec de Mori that distinct postures of listening indeed led to different understandings of auditory agency. ${ }^{97}$ Agency, more generally, is not a property of the objects themselves but "a culturally prescribed framework for thinking about causation". ${ }^{98}$ From a cognitive point of view, an agent is an object which occupies a special kind of position in an observer's understanding of a causal network. Agency in this sense is always abducted. ${ }^{99}$ In theory, chains of cause and effect could be pursued to the infinite (every effect has a cause and so on). In practice, brains always stop short and consider that some entities just act "by themselves". Those beings are agents (for the time they occupy that position). In Gell's words, an agent is "the source, the origin, of causal events, independently of the state of the physical universe". ${ }^{100}$

71 This definition has some interesting consequences. Firstly, agency is not a stable property of particular kinds of objects. It merely has prototypes: kinds of beings which are more often than others considered agents. A human for instance can be an agent now and not be an agent later (the "lone wolf" terrorist and the obeying soldier are not equally agentive when they kill, a distinction that has juridical consequences, for example). Secondly, agency is not an optional "belief" but a low-level requirement of human cognition. Something is always needed at the end of the causal chain. It could be a human, a tree, a dog, a stone, a sound, or an unseen being whose existence is abducted from its effects (a spirit or a virus for instance). What is the agent affects how the observer understands the situation, but not the nature of agency: that being "acts" because the observer holds it to be an autonomous source of causation. Lastly, agency is distinct from intentionality. An agentive being appears to have the intrinsic capacity to initiate actions "by itself". The observer abducts an autonomous force in it. It does not follow that the observer also assigns to it intentions, mindfulness or will.

Non-human agencies can then be conceived in sound without resorting to the "mysterious rhetoric of music-as-magic of times bygone". ${ }^{101}$ Causal chains must end somewhere, and sometimes ending them in the auditory realm is just what people do. To place agency in sounds, an observer must adopt a specific posture of listening. ${ }^{102}$ Sounds then appear to cause each other through a kind of intrinsic logic, instead of just being caused (as the observer still knows) by their physical sources. Agency refers to the additional fact that some of these "enchanted" sounds do not seem to just result from each other, in a causal sense, but also appear to the observer as autonomous sources of causation. These are prototypical agents, whose effects tend to propagate into the non-auditory social world (starting usually with the listener's own self). To 
paraphrase Gell, sounds are social agents when they are the direct "other" of social interactions. ${ }^{103}$

Sound agency is related to the ontology of auditory experience: what beings exist for the listener and what properties they have. To say that the terrorist and the soldiers listened to (different kinds of) "music" is therefore not enough. What they listened to was in effect as different as an emotionally charged "soundscape" can be from a "mad aggressor". The former enables self-conscious wanderings in which a mass murderer can come to think that he is a martyr. The latter suggests a direct encounter with a social "other" in a context of considerable boredom and general mistrust.

\section{BIBLIOGRAPHY}

BECKER Judith, Deep Listeners: Music, Emotion, and Trancing, Bloomington, Indiana University Press, 2004.

BERWICK Andrew, “2083 - A European Declaration of Independence”, London, 2011.

BEYDOUN Khaled A, "Lone Wolf Terrorism: Types, Stripes, and Double Standards", Northwestern University Law Review, vol. 112, no. 5, 2018, 2018, p. 32.

BJORøY Karl-Magnus and HAWKINS Stan, “"When light turns into darkness': Inscriptions of music and terror in Oslo 22 July 201", KNUDSEN Jan Sverre, SKÅNLAND Marie Strand and TRONDALEN Gro (eds.), Musikk etter 22. juli [Music after 22 Juli], Oslo, Norwegian Academy of Music, 2014, pp. 139-161.

BOWDEN Mark, The Kabul-ki Dance, https://www.theatlantic.com/magazine/archive/2002/11/thekabul-ki-dance/302610, accessed on November 8, 2018.

BULL Michael, Sounding Out the City: Personal Stereos and the Management of Everyday Life, Oxford, Berg, 2000.

CLAYTON Martin, "Introduction: Towards a Theory of Musical Meaning (In India and Elsewhere)", British Journal of Ethnomusicology, vol. 10, no. 1, 2001, pp. 1-17.

COKER Christopher, The Future of War. The Re-Enchantment of War in the Twenty-First Century, Malden,Oxford,Victoria, Blackwell, 2004.

CUSICK Suzanne G. and JOSEPH Branden W., "Across an Invisible Line: A Conversation about Music and Torture", Grey room, no. 42, 2011, pp. 6-21.

DAUGHTRY J. Martin, Listening to War. Sound, Music, Trauma, and Survival in Wartime Iraq, Oxford; New York, Oxford University Press, 2015.

DENORA Tia, Music Asylums: Wellbeing Through Music in Everyday Life, Farnham, Surrey; Burlington, VT, Ashgate, 2013.

DENORA Tia, Music in Everyday Life, Cambridge; New York, Cambridge University Press, 2003. 
DOKIC Jérôme, HATTEN Robert S, INGOLD Tim, KREUTZER Michel and TOLBERT Elizabeth, "Comments on 'Postures of listening' by Victor A. Stoichita and Bernd Brabec de Mori”, Terrain. Anthropologie \& sciences humaines, 2018, http://journals.openedition.org/terrain/17547.

DOYLE Peter, Echo and Reverb: Fabricating Space in Popular Music, 1900-1960, 1900-1960, Middletown, Wesleyan University Press, 2005.

FRIEDSON Steven M., "The Music Box: Songs of Futility in a Time of Torture”, Ethnomusicology, vol. 63 , no. 2, 2019, pp. 222-246.

GELL Alfred, Art and Agency. An Anthropological Theory, Oxford, Clarendon Press, 1998.

GIBSON James J., The Ecological Approach to Visual Perception, London, Taylor \& Francis, 1986.

GILMAN Lisa, "Grounding the Troops: Music, Place, and Memory in the Iraq War", Volume! La revue des musiques populaires, vol. 10, no. 1, 2013, pp. 172-190.

GILMAN Lisa, “An American Soldier's iPod: Layers of Identity and Situated Listening in Iraq", Music and Politics, vol. IV, no. 2, 2010, p. 7, https://dx.doi.org/10.3998/mp.9460447.0004.201.

GRANT Morag Josephine, “Music during Battle: Representation and Reality”, JARDIN Étienne (ed.), Music and War in Europe from the French Revolution to WWI, Turnhout, Brepols, 2016, pp. 29-44. GRANT Morag Josephine, "Bagpipes at the Front: Pipers and Piping during Combat in the Great War", schrAmm Michael (ed.), Militärmusik und Erster Weltkrieg, Bonn, Militärmusikzentrum der Bundeswehr, 2015, pp. 35-67.

KRUEGER Joel, "Musicing, Materiality, and the Emotional Niche", Action, Criticism, and Theory for Music Education, vol. 14, no. 3, 2015, pp. 43-62.

LAKOFF George and JOHNSON Mark, Metaphors We Live By, Chicago and London, University of Chicago Press, 1980.

LEONARD Cecilia H., ANNAS George D., KNOLL James L. and TøRRISSEN Terje, “The Case of Anders Behring Breivik - Language of a Lone Terrorist”, Behavioral Sciences \& the Law, vol. 32, no. 3, 2014, pp. 408-422.

OLDS Ian and ScOTT Garett, Occupation: Dreamland, Rumur Releasing, 2005.

PIDD Helen, “Anders Behring Breivik cries during own propaganda film”, The Guardian, https:// www.theguardian.com/world/2012/apr/16/anders-behring-breivik-cries-own-propaganda-film, $04 / 16 / 2012$.

PIESLAK Jonathan R., Sound Targets: American Soldiers and Music in the Iraq War, Bloomington, Indiana University Press, 2009.

RANSTORP Magnus, “'Lone Wolf Terrorism'. The Case of Anders Breivik”, Sicherheit \& Frieden, vol. 31, no. 2, 2013, pp. 87-92.

SтогснітA Victor A., "Musicopathies. La musique est-elle bonne pour la santé ?", Terrain. Anthropologie \& sciences humaines, no. 68, 2017, pp. 4-25.

STOICHITA Victor A. and BRABEC DE MORI Bernd, "Postures of listening. An ontology of sonic percepts from an anthropological perspective", Terrain. Anthropologie \& sciences humaines, 2017, http:// journals.openedition.org/terrain/16418.

STOICHITA Victor A. and BRABEC DE MORI Bernd, "Response to comments on 'Postures of listening"', Terrain. Anthropologie \& sciences humaines, 2018, http://journals.openedition.org/terrain/17579. 
STROUD Joe, "The Importance of Music to Anders Behring Breivik", Contemporary Voices: St Andrews Journal of International Relations, vol. 4, no. 1, 2013, https://doi.org/10.15664/jtr.620.

SUMERA Matthew, “The Soundtrack to War”, WHITEHEAD Neil L. and FINNSTRÖM Sverker (eds.), Virtual War and Magical Death: Technologies and Imaginaries for Terror and Killing, Durham (NC), Duke University Press, 2013, pp. 214-233.

TEITELBAUM Benjamin, “'The Path of Dreams': Breivik, Music, and Neo-Nazi Skinheadism”, KNUDSEN Jan Sverre, SKÅNLAND Marie Strand and TRONDALEN Gro (eds.), Musikk etter 22.juli [Music after 22 Juli], Oslo, Norwegian Academy of Music, 2014, pp. 119-138.

VOLCLER Juliette, Le son comme arme. Les usages policiers et militaires du son, Paris, La Découverte, 2011.

WALSER Robert, "Rhythm, Rhyme, and Rhetoric in the Music of Public Enemy", Ethnomusicology, vol. 39, no. 2, 1995, pp. 193-217.

WALSER Robert, Running with the Devil. Power, Gender, and Madness in Heavy Metal Music, Middletown, Wesleyan University Press, 1993.

WHITEHEAD Neil L. and FINNSTRÖM Sverker, Virtual War and Magical Death: Technologies and Imaginaries for Terror and Killing, Durham (NC), Duke University Press, 2013.

WHITELEY Sheila, "Progressive Rock and Psychedelic Coding in the Work of Jimi Hendrix", Popular Music, vol. 9, no. 1, 1990, p. 37.

WILSON Scott, "Jonathan Pieslak, Sound Targets: American Soldiers and Music in the Iraq War", Volume! La revue des musiques populaires, vol. 9, no. 2, 2012, pp. 243-245.

WILSON Scott, Great Satan's Rage: American Negativity and Rap/metal in the Age of Supercapitalism, Oxford, Oxford University Press, 2015

\section{NOTES}

1. STOICHITA Victor A. and BRABEC DE MORI Bernd, "Postures of listening. An ontology of sonic percepts from an anthropological perspective", Terrain. Anthropologie \& sciences humaines, 2017, http://journals.openedition.org/terrain/16418.

2. DENORA Tia, Music in Everyday Life, Cambridge; New York, Cambridge University Press, 2003, p. 44.

3. "Musicing, Materiality, and the Emotional Niche", Action, Criticism, and Theory for Music Education, vol. 14, no. 3, 2015, pp. 43-62.

4. CLAYTON Martin, "Introduction: Towards a Theory of Musical Meaning (In India and Elsewhere)", British Journal of Ethnomusicology, vol. 10, no. 1, 2001, p. 4.

5. DeNora's own argument frequently resorts to shortcuts like "music's power" and syntactic structures in which music is an autonomous agent. For example, if indeed "music may take actors unaware" (DENORA, Music in Everyday Life, p. 162), then their agency in this process is at best disputable.

6. GIBSON James J., The Ecological Approach to Visual Perception, London, Taylor \& Francis, 1986, p. 127, emphasis in the original.

7. Ibid., p. 129.

8. Ibid., p. 134

9. DENORA, Music in Everyday Life, p. 40. 
10. I follow Gilman in using "the term 'soldier' generically to refer to those in the military in any branch, understanding that 'the soldiers' officially refers only to those serving in the U.S. Army", GILMAN Lisa, "Grounding the Troops: Music, Place, and Memory in the Iraq War", Volume! La revue des musiques populaires, vol. 10, no. 1, 2013, p. 174.

11. PIESLAK Jonathan R., Sound Targets: American Soldiers and Music in the Iraq War, Bloomington, Indiana University Press, 2009, p. 31sqq; DAUGHTRY J. Martin, Listening to War. Sound, Music, Trauma, and Survival in Wartime Iraq, Oxford; New York, Oxford University Press, 2015, p. 232.

12. sтоіснітA Victor A., "Musicopathies. La musique est-elle bonne pour la santé ?", Terrain. Anthropologie \& sciences humaines, no. 68, 2017, pp. 4-25.

13. GILMAN Lisa, “An American Soldier's iPod: Layers of Identity and Situated Listening in Iraq", Music and Politics, vol. IV, no. 2, 2010, p. 7, https://dx.doi.org/10.3998/mp.9460447.0004.201.

14. WILSON Scott, "Jonathan Pieslak, Sound Targets: American Soldiers and Music in the Iraq War," Volume! La revue des musiques populaires, vol. 9, no. 2, 2012, pp. 243-245.

15. WHITEHEAD Neil L. and FINNSTRÖM Sverker, Virtual War and Magical Death: Technologies and Imaginaries for Terror and Killing, Durham (NC), Duke University Press, 2013.

16. Anders Behring Breivik changed his name to Fjotolf Hansen in 2017. He signed his compendium as Andrew Berwick. Here, I use Breivik throughout to refer to the man, and his pen name to cite his compendium in accordance with bibliographical conventions.

17. BEYDOUN Khaled A, "Lone Wolf Terrorism: Types, Stripes, and Double Standards", Northwestern University Law Review, vol. 112, no. 5, 2018, p. 1218.

18. BERWICK Andrew, “2083 - A European Declaration of Independence”, London, 2011, p. 845.

19. LEONARD Cecilia H., ANNAS George D., KNOLL James L. and TøRRISSEN Terje, "The Case of Anders Behring Breivik - Language of a Lone Terrorist”, Behavioral Sciences \& the Law, vol. 32, no. 3, 2014, pp. 408-422.

20. Ibid., p. 416.

21. Ibid., p. 417.

22. RANSTORP Magnus, “'Lone Wolf Terrorism'. The Case of Anders Breivik”, Sicherheit \& Frieden, vol. 31, no. 2, 2013, p. 89.

23. Ibid., p. 91.

24. Ibid., p. 89.

25. Breivik mentions three tracks which for him "surpass almost anything [he's] heard before" (Berwick, “2083 - A European Declaration of Independence”, p. 849) : The Dreaming - Ere the World Crumbles / Nighttime journey through the Eiglophian mountains (Ascending Cimmeria) / The Dreaming Anew - Memories of Cimmeria.

26. This version can easily be found on YouTube. It is more difficult to find it in the film, however Breivik writes that it was "performed during the most intense fighting of one of the central battles" (Ibid). According to Stroud (STROuD Joe, "The Importance of Music to Anders Behring Breivik", Contemporary Voices: St Andrews Journal of International Relations, vol. 4, no. 1, 2013, p. 10, https://doi.org/10.15664/jtr.620), it was used only in the trailer of Lord of the Rings. However, fans of the movie have used it extensively to soundtrack their home-made resamples of their favourite scenes of the film. Such resamples abound on YouTube.com. Only there can the soundtrack version be heard in full length. This soundtracking of battle scenes closely resembles the "war videos" produced by American soldiers.

27. STROUD, "The Importance of Music to Anders Behring Breivik".

28. Ibid., p. 11.

29. “'The Path of Dreams': Breivik, Music, and Neo-Nazi Skinheadism”, KNUDSEN Jan Sverre, SKÅNLAND Marie Strand and TRONDALEN Gro (eds.), Musikk etter 22. juli [Music after 22 Juli], Oslo, Norwegian Academy of Music, 2014, pp. 119-138.

30. Ibid., p. 136.

Transposition, Hors-série 2| 2020 
31. A thorough analysis of these lyrics would be beyond the scope of this article. It should be mentioned however that some songs cited by Breivik deviate from the general enunciative strategy described here. For instance, in Hypocrite, the second person is prominent and the tone accusative: "You complain about the politicians but still you vote them in / You've lost your soul, you coward; to sell your pride is a sin." The listener could here identify with the second person in a kind of self-bashing or, more probably, he or she will join the utterer and accuse others of hypocrisy. My general point is that the lyrics to which Breivik seems receptive easily allow the listener to move into the first-person agentive position.

32. For a detailed musicological analysis of "The dreaming anew", see BJORøY Karl-Magnus and HAWKINS Stan, “"When light turns into darkness': Inscriptions of music and terror in Oslo 22 July 201,” KNUDSEN Jan Sverre, SKÅNLAND Marie Strand and TRONDALEN Gro (eds.), Musikk etter 22. juli [Music after 22 Juli], Oslo, Norwegian Academy of Music, 2014, pp. 139-161, p. 155.

33. BERWICK, “2083 - A European Declaration of Independence”, p. 849.

34. BJORøY Karl-Magnus and HAWKINS Stan, “'When light turns into darkness': Inscriptions of music and terror in Oslo 22 July 201", KNUDSEN Jan Sverre, SKÅNLAND Marie Strand and TRONDALEN Gro (eds.), Musikk etter 22. juli [Music after 22 Juli], p. 141.

35. PIESLAK, Sound targets, p. 26.

36. Ibid., p. 47; WALSER Robert, Running with the Devil. Power, Gender, and Madness in Heavy Metal Music, Middletown, Wesleyan University Press, 1993, p. 11.

37. BERWICK, "2083 - A European Declaration of Independence", p. 249.

38. See BULL Michael, Sounding Out the City: Personal Stereos and the Management of Everyday Life, Oxford, Berg, 2000, p. 85sqq.

39. sтогснітA, "Musicopathies. La musique est-elle bonne pour la santé ?".

40. On the uses of reverb as an acoustic index of space in American popular musics, see DOYLE, Echo and Reverb: Fabricating Space in Popular Music, 1900-1960, Middletown, Wesleyan University Press, 2005.

41. STROUD, "The Importance of Music to Anders Behring Breivik", p. 9; BJORøY and HAWKINS, “'When light turns into darkness': Inscriptions of music and terror in Oslo 22 July 201”, p. 155.

42. PIDD Helen, "Anders Behring Breivik cries during own propaganda film", The Guardian, https://www.theguardian.com/world/2012/apr/16/anders-behring-breivik-cries-own-

propaganda-film, 04/16/2012.

43. RANSTORP, “'Lone Wolf Terrorism'. The Case of Anders Breivik”, p. 90.

44. Breivik did kill an unarmed policeman upon his arrival on the island of Utøya. He later surrendered without resistance to the special forces deployed to intercept him.

45. This complaint was reported in various newspapers. See for instance SAUL Heather, "Anders Breivik: Mass murderer demands better video games and threatens hunger strike over jail "hell," The Independent, 02/15/2014. For more context on Breivik's relation with the media after his incarceration, see DESHAYES, La lettre de l'assassin, https://making-of.afp.com/la-lettre-delassassin, consulted on 8 July 2019.

46. BERWICK, "2083 - A European Declaration of Independence”, pp. 631, 1390.

47. DAUGHTRY J. Martin, Listening to War; PIESLAK, Sound targets; GILMAN, “An American Soldier's iPod"; GILMAN, "Grounding the Troops"; VOLCLER Juliette, Le son comme arme. Les usages policiers et militaires du son, Paris, La Découverte, 2011.

48. PIESLAK, Sound targets, p. 42sqq.

49. SUMERA Matthew, “The Soundtrack to War", WHITEHEAD Neil L. and FINNSTRÖM Sverker (eds.), Virtual War and Magical Death: Technologies and Imaginaries for Terror and Killing, Durham (NC), Duke University Press, 2013, pp. 214-233.

50. Ibid.; PIESLAK, Sound targets, p. 27 sqq.

51. GILMAN, “An American Soldier's iPod”, p. 6. 
52. "The Soundtrack to War", p. 234.

53. Eric, quoted by GILMAN, “An American Soldier's iPod”, p. 9.

54. DAUGHTRY, Listening to War, pp. 220-225.

55. GILMAN, “An American Soldier's iPod”, p. 5.

56. DAUGHTRY, Listening to War, p. 20.

57. PIESLAK, Sound targets, p. 150.

58. Ibid., p. 152.

59. Whiteley Sheila, "Progressive Rock and Psychedelic Coding in the Work of Jimi Hendrix", Popular Music, vol. 9, no. 1, 1990, p. 86 quoted in Pieslak 2009 p. 169.

60. DENORA Tia, Music Asylums: Wellbeing Through Music in Everyday Life, Farnham, Surrey; Burlington, VT, Ashgate, 2013, p. 138.

61. Ibid., p. 113.

62. WILSON Scott, Great Satan's Rage: American Negativity and Rap/metal in the Age of Supercapitalism, Oxford, Oxford University Press, 2015.

63. For a precise historical example see GRANT Morag Josephine, "Bagpipes at the Front: Pipers and Piping during Combat in the Great War", sснRAMm Michael (ed.), Militärmusik und Erster Weltkrieg, Bonn, Militärmusikzentrum der Bundeswehr, 2015, pp. 35-67. The Scottish Highland regiments of the British Army used bagpipe music as an incentive during the battle until after World War I. Grant's analysis of historical sources shows that the role of the piper's music on the battlefield was not to promote aggression or the willingness to kill. Instead, "the piper provided reassurance and a focal point in an essentially inhumane and chaotic environment". To that effect, he would play popular songs, dance tunes and regimental marches. These were drawn "largely from the wider repertoire of Scottish songs and tunes, supplemented with newer tunes written specifically for the pipes and often commemorating certain campaigns, events or persons." In effect, piper's music at war stood for ideas of homeland and social bonding, rather than for the battle as a violent encounter. Other examples of pipers' military repertoire and its reception are analyzed in GRANT Morag Josephine, "Music during Battle: Representation and Reality", JARDIN Étienne (ed.), Music and War in Europe from the French Revolution to WWI, Turnhout, Brepols, 2016, pp. 29-44.

64. GILMAN, "Grounding the Troops," pp. 4-7.

65. GILMAN, "Grounding the Troops", p. 9.

66. Sergeant 1st Class Grisham, quoted by PIESLAK, Sound targets, p. 69.

67. A "secular" kind of trancing according to BECKER Judith, Deep Listeners: Music, Emotion, and Trancing, Bloomington, Indiana University Press, 2004, p. 2.

68. PIESLAK, Sound targets, p. 165.

69. For instance in SUMERA, "The Soundtrack to War," p. 218: "Trancing is exactly what these warriors engage in during practices of collective listening prior to going out on patrol".

70. See for instance the Balinese Rangda/Barong ritual in Becker, Deep Listeners. Music, Emotion and Trancing, p. 84, to which Pieslak also refers.

71. This was also the official regulation, see DAUGHTRY, Listening to War, p. 234.

72. Sgt N. Saunders, quoted by PIESLAK, Sound targets, p. 56.

73. Ibid., pp. 31-44.

74. DAUGHTRY, Listening to War, p. 232.

75. The same Grisham, quoted by PIESLAK, Sound targets, p. 55.

76. DENORA, Music in Everyday Life, p. 27.

77. LAKOFF George and JOHNSON Mark, Metaphors We Live By, Chicago and London, University of Chicago Press, 1980, p. 5.

78. I follow Lakoff and Johnson's typographical convention in capitalizing references to concepts and metaphors (as opposed to the actual things to which they refer in the world). 
79. LAKOFF and JOHNSON, Metaphors We Live By, p. 5.

80. There is, in this respect, a difference between the war against the regular Iraqi army (March to May 2003) and the rest of the American intervention in Iraq and Afghanistan.

81. WILSON, "Jonathan Pieslak, Sound Targets".

82. BOWDEN Mark, The Kabul-ki Dance, https://www.theatlantic.com/magazine/archive/2002/11/ the-kabul-ki-dance/302610/, accessed on November 8, 2018.

83. One soldier in a tank, in GITTOES George, Soundtrack to War, ABC Video, 2005 at 8:23.

84. Pfc Thomas Turner, in OLDS Ian and scotT Garett, Occupation: Dreamland, Rumur Releasing, 2005 at 25:02.

85. 1st Lieutnant Matt Bacik, Ibid. at 26:46.

86. The instrumental track is available at https://www.youtube.com/watch?v=DePcSUopqSw

87. WALSER Robert, "Rhythm, Rhyme, and Rhetoric in the Music of Public Enemy", Ethnomusicology, vol. 39, no. 2, 1995, pp. 193-217.

88. WALSER, Running with the Devil. Power, Gender, and Madness in Heavy Metal Music.

89. cusicK Suzanne G. and JOSEPH Branden W., "Across an Invisible Line: A Conversation about Music and Torture", Grey room, no. 42, 2011, p. 11.

90. There were of course important differences too. Perhaps the most significant, for a discussion of music's effects, is that, by all detainee accounts, music stopped sounding like music during sessions of loud and prolonged exposure to the same repeated track. It became just "banging", "hammering" on the head, and the unfortunate listeners lost any other sense of rhythm, harmony or melodic structure. In a recent investigation on the divergence between musical torture and musical possession (both of which would seem to dismantle an individual's normal self), Friedson pointed to another important difference related to the management of time. "The temporality of musical experience, its durée, has the uncanny ability, in both no-touch torture and shrine rituals, to bite into the very realm of existence not in order to dissolve it but in order to become it" (FRIEDSON Steven M., "The Music Box: Songs of Futility in a Time of Torture," Ethnomusicology, vol. 63, no. 2, 2019, pp. 222-246, p. 236). Friedson goes on to say that in musical torture, entrainment is totally asymmetrical, imposed from above and unpredictable in both its occurrence and its duration. Its psychological purpose is "learned helplessness". At shrine rituals on the contrary, music's stable and prolonged repetition provides a predictable structure onto which the listener can latch in order to enter a "musical plane of multiplicity".

91. WHITEHEAD and FINNSTRÖM, Virtual war and magical death, p. 8.

92. Ibid., p. 1.

93. DENORA, Music Asylums, p. 63.

94. COKER Christopher, The Future of War. The Re-Enchantment of War in the Twenty-First Century, Malden; Oxford; Victoria, Blackwell, 2004, p. 130.

95. One might think for instance of "aerobic" music to which Western listeners also lend many energizing properties, see DENORA, Music in Everyday Life, p. 89sqq.

96. According to Gilman, the social position of the (often underprivileged) artists could have mattered to some soldiers who considered themselves as also subaltern and were "engaging similar negotiations of power and powerlessness" (GILMAN, "An American Soldier's iPod”, p. 7). However, the same author elsewhere indicates that "many soldiers described selecting music because they considered the artists and genres to be far removed from their current realities" (GILMAN, "Grounding the Troops," p. 10). The types of music to which each of these comments refers is unclear.

97. STOICHITA and BRABEC DE MORI, "Postures of listening. An ontology of sonic percepts from an anthropological perspective". For a detailed discussion see DOKIC Jérôme, HATTEN Robert S, INGOLD Tim, KREUTZER Michel and TOLBERT Elizabeth, "Comments on 'Postures of listening' by Victor A. Stoichita and Bernd Brabec de Mori”, Terrain. Anthropologie \& sciences humaines, 2018, http:// 
journals.openedition.org/terrain/17547 and STOICHITA Victor A. and BRABEC DE MORI Bernd, "Response to comments on 'Postures of listening", Terrain. Anthropologie \& sciences humaines, 2018, http://journals.openedition.org/terrain/17579.

98. GELL Alfred, Art and Agency. An Anthropological Theory, Oxford, Clarendon Press, 1998, p. 17.

99. Ibid., p. 15. Abduction is a kind of reasoning whereby causes are inferred from observing their (alleged) consequences. It is, strictly speaking, a syllogism because a consequence could have several different causes. Its validity therefore remains hypothetical, but it is nevertheless commonly used and usually efficient in orienting one's actions in practice. Gell made the point that whenever people consider that a being acts autonomously, "by itself", they abduct its agency from observed disturbances in its vicinity.

100. GELL, Art and Agency, p. 16.

101. DENORA, Music Asylums, p. 141. DeNora herself wants "a revised notion of music as magic, in particular what might be termed a 'magic realist' theory of how music helps, a focus on how music can convert us from one state of being or mode of consciousness to another, in ways that are produced through concrete and practical actions and on craft, a focus expressly devoted to what people do with and attribute to music in specific settings" (Ibid). What remains to be addressed in this program is what happens when people find in music not just affordances, but also autonomous causation and agency.

102. STOICHITA and BRABEC DE MORI, "Postures of listening. An ontology of sonic percepts from an anthropological perspective".

103. GELL, Art and Agency, p. 17.

\section{ABSTRACTS}

During the wars in Iraq and Afghanistan, some American soldiers commonly listened to music in order to "motivate" themselves before action. Previous studies have shown that their most frequent choices to this effect pertained to two genres: "gangsta" rap and heavy metal. At another extreme of armed violence, Norwegian terrorist Anders Behring Breivik reported listening to a selection of tunes in the preparation of his 2011 massacre and possibly also during its perpetration. His musical choices sounded radically different from metal and rap. Yet, all of these styles of music had previously been associated with graphic violence throughout popular movies and video games. This paper asks how each type of music "worked" in motivating its listener for armed confrontation. The comparison requires going beyond the fact that mainstream media interact with common imaginaries of violence. The hypothesis here is that the differences between the terrorist's and the soldier's playlists reflect deeper contrasts in their engagements with the opponent. This case study of musical "motivation" leads to a broader discussion of the interplay between the agency of the listener, as opposed to the agency which he or she sometimes locates in the music itself.

Durant les guerres en Irak et Afghanistan, certains soldats états-uniens écoutaient régulièrement de la musique pour « se motiver » avant de partir en mission. Les études existantes montrent que leurs choix s'orientaient principalement vers deux genres : le « gangsta » rap et le heavy metal. À un autre extrême de la violence armée, le terroriste norvégien Anders Behring Breivik affirmait avoir fréquemment écouté de la musique pour préparer son massacre de 2011. Ses choix musicaux étaient radicalement différents de ceux des soldats états-uniens. Néanmoins, ses 
musiques comme celles des soldats avaient été fréquemment associées à des scènes de violence dans l'industrie des films et des jeux vidéo. Cet article interroge la manière dont ces musiques purent s'avérer «fonctionnelles" pour motiver leurs auditeurs en vue de la confrontation. La comparaison proposée requiert de dépasser le constat que les médias grand public interagissent avec les imaginaires individuels de la violence. L'hypothèse envisagée ici est que les différences entre les choix musicaux du terroriste et ceux des soldats reflètent un contraste plus profond dans leurs manières d'envisager la confrontation. Les cas de « motivation » ici étudiés conduisent aussi à une discussion plus large de la qualité d'agent dont certains auditeurs investissent certaines des musiques qu'ils écoutent.

\section{INDEX}

Keywords: affordance, agency, soundtrack, war, terrorism

Mots-clés: affordance, agentivité, cinéma, guerre, terrorisme

\section{AUTHOR}

\section{VICTOR A. STOICHITA}

Victor A. Stoichita investigates musical interactions at the crossroads of anthropology, ethnomusicology and cognitive science. He worked with Roma professional musicians in Romania to understand why they relate the effects of their music to concepts like "cunning" and "slyness". This led him to broader investigations of virtuosity, musical irony, and techniques of enchantment through sound. Victor A. Stoichita is a fellow of the Centre for Ethnology and Comparative Sociology at the French National Centre for Scientific Research (LESC/CNRS). 